\title{
Seabird bycatch in the Brazilian pelagic longline fishery and a review of capture rates in the southwestern Atlantic Ocean
}

\author{
Leandro Bugoni ${ }^{1,2, *}$, Patricia L. Mancini ${ }^{1}$, Danielle S. Monteiro ${ }^{3,4}$, \\ Loretha Nascimento ${ }^{1}$, Tatiana S. Neves ${ }^{1}$ \\ ${ }^{1}$ Projeto Albatroz, Av. dos Bancários 76/22, Ponta da Praia, CEP 11030-300, Santos-SP, Brazil \\ ${ }^{2}$ Institute of Biomedical and Life Sciences, Graham Kerr Building, University of Glasgow, Glasgow G12 8QQ, UK \\ ${ }^{3}$ Núcleo de Educação e Monitoramento Ambiental - NEMA, R. Maria Araújo 450, Cassino, CEP 96207-480, \\ Rio Grande-RS, Brazil \\ ${ }^{4}$ Fundação Universidade Federal do Rio Grande, Laboratório de Elasmobrânquios e Aves Marinhas, C.P. 474, \\ CEP 96201-900, Rio Grande-RS, Brazil
}

\begin{abstract}
The southwestern Atlantic Ocean is an important foraging ground throughout the year for several albatross and petrel species. Longline fishing fleets in the region currently pose the main threat for this group of seabirds at sea, and conservation measures are urgently required. We present information on bycatch rates of seabirds in the Brazilian domestic pelagic longline fishery from 2001 to 2007, and review bycatch rates reported for the demersal and pelagic longline fisheries in the southwestern Atlantic Ocean. Overall seabird capture rate for the Brazilian pelagic longline fleet during 63 cruises (656 sets and 788446 hooks) was 0.229 birds per 1000 hooks, varying from 0 to 0.542 according to season. Capture rates were higher between June and November (cold season) and affected mainly the black-browed albatross Thalassarche melanophris (55\% of birds captured), the white-chinned petrel Procellaria aequinoctialis, the spectacled petrel Procellaria conspicillata and the Atlantic yellow-nosed albatross Thalassarche chlororhynchos. Capture rates previously reported in the SW Atlantic varied from 0 to 5.03 birds per 1000 hooks, with those reports based on logbooks or fishermen interviews tending to underestimate capture rates, whereas those based on small numbers of hooks or short time periods tend to greatly overestimate rates in both pelagic and demersal longline fisheries. Previous studies have played an important role in delimiting the seabird bycatch problem, forming a baseline for mitigation actions and serving as a guide for improvements in data collection. However, data collected by onboard seabird-dedicated observers are more reliable, provide a greater range of information relating to bycatch, and form a baseline for more robust analysis and addressing further questions. The current study highlights the stochastic nature of seabird fatalities in longline fisheries and the need for extensive sampling to obtain realistic estimates of capture rates covering different years, seasons, vessels, and the range of fishing gear and practices.
\end{abstract}

KEY WORDS: Albatrosses · Petrels · Longline · Incidental capture · Review · Brazil · Fisheries Resale or republication not permitted without written consent of the publisher

\section{INTRODUCTION}

The main reason for the current decline of many albatross and petrel populations around the world is bycatch in fisheries, particularly in pelagic longline fisheries (Gales 1997, Montevecchi 2002, BirdLife International 2004). Fishing activities can have short- term beneficial effects for seabirds, by bringing them otherwise unavailable food in the form of offal or discharged demersal fish and by removing competitors, but can also have direct adverse effects by depleting stocks of seabirds' prey or by causing seabird mortalities through drowning in nets or on longline hooks (Thompson \& Riddy 1995, Montevecchi 2002, Furness 
2003). In the medium- to long term, or from a community perspective, fishing discards appear to be detrimental, for example in that they affect other seabird species (Votier et al. 2004) or because they provide low-quality fishery wastes which affect breeding performance (Grémillet et al. 2008).

The impact of bycatch on seabird populations around the world is the focus of considerable international concern, and incidental capture in longline fisheries is considered the most serious seabird-fishery issue for the conservation of several Procellariiformes (Gales 1997, Brothers et al. 1999, Furness 2003), being implicated in marked declines of several populations (Gales 1997, Nel et al. 2002, Tuck et al. 2001, Cuthbert et al. 2004). Currently, 19 out of 21 albatross species are under risk of extinction (BirdLife International 2004). In the southwestern (SW) Atlantic Ocean different fisheries are detrimental to albatrosses and petrels, including trawling (Sullivan et al. 2006), gillnetting (Perez \& Wahrlich 2005, Neves et al. 2006a), a range of artisanal or semi-industrial hook-and-line fisheries (Bugoni et al. 2008), and industrial bottom and pelagic longlines (Neves \& Olmos 1997, Favero et al. 2003).

The community of pelagic seabirds in the SW Atlantic Ocean, and particularly off Brazil, is dominated, in terms of number of species and individuals, by albatrosses and petrels which breed in other areas such as Tristan da Cunha, Malvinas/Falkland Islands, South Georgia, Antarctic and New Zealand, and feed off Brazil during both the breeding and wintering periods (Olmos 1997, Neves et al. 2006a). This community shows seasonal variations, with low abundance in warm months and increasing abundance in cold months due to the arrival of Antarctic and sub-Antarctic migrants, which constitute the bulk of seabird on offshore waters (Olmos 1997, Neves et al. 2006a,b). The only Procellariiformes species breeding in Brazil is the Audubon's shearwater Puffinus lherminieri, with a few pairs on islands off the southeastern and northeastern coasts (Efe \& Musso 2001), and the Trindade petrel Pterodroma arminjoniana on Trindade Island (Luigi et al. 2008). In total, 10 albatross (Diomedeidae) and 31 petrel (Procellariidae, Hydrobatidae and Pelecanoididae) species are recorded in Brazil (CBRO 2007).

In this study we present data on capture rates for the Brazilian pelagic longline fishery from 2001 to 2007 and abundance of seabirds attending longline vessels just before longline setting; we described the dynamics and magnitude of the pelagic fishing effort of the Brazilian domestic and leased fleets and their overlap with seabird distribution. In addition, a critical review of capture rates in longline fisheries reported in the SW Atlantic Ocean is provided. Gaps in our knowledge on seabird bycatch in the region, as well as conservation needs are discussed.

\section{MATERIALS AND METHODS}

Data on seabird interactions with longline fisheries were collected in a large area over the Brazilian Exclusive Economic Zone (EEZ) and adjacent international waters, from 22 to $38^{\circ} \mathrm{S}$ and 26 to $53^{\circ} \mathrm{W}$ (Fig. 1). Fishing grounds in the SW Atlantic are under the influence
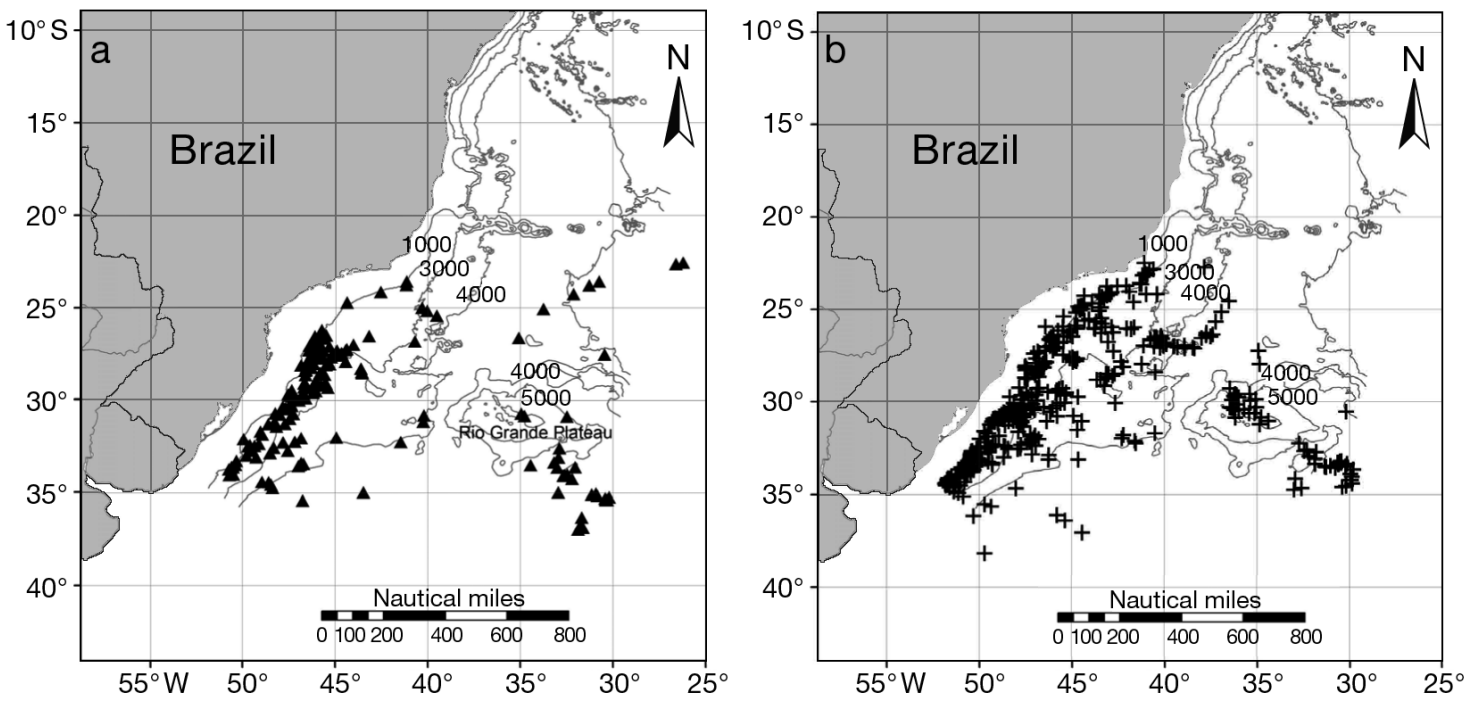

Fig. 1. Locations of 656 pelagic longline settings for the domestic fleet off the Brazilian coast sampled by onboard seabird observers from 2001 to 2007 for (a) warm months from December to May, $\mathrm{n}=176$ sets, and (b) cold months from June to November, $\mathrm{n}=480$ sets. The division between the Brazilian Current flowing southward and the Falkland Current flowing northward varies annually and seasonally, from 35 to $39^{\circ} \mathrm{S}$ 
of the Subtropical Convergence, where cold waters of the Malvinas/Falkland Current flowing northward meet the warm waters of the Brazilian Current flowing southward (Garcia 1998). The presence of highly productive waters from the Malvinas/Falkland Current in winter sustains an important pelagic longline fishery in southern Brazil (Castello 1998), as well as the most abundant and diverse seabird community in Brazil (Neves et al. 2006b). Over the Patagonian shelf, where the Malvinas/Falkland Current flows, demersal longline fisheries occur. The division between the Brazilian and Falklands Currents varies seasonally, from 35.8 to $38.6^{\circ} \mathrm{S}$, forming a heterogeneous area between both currents up to $1000 \mathrm{~km}$ wide with many eddies and fronts (Olson et al. 1988).

The Brazilian pelagic longline fishery consists basically of 2 distinct fleets (but see Neves et al. 2006a and Bugoni et al. 2008) in terms of fishing gear characteristics and governmental management. The leased fleet is composed of foreign medium to large vessels (30 to $50 \mathrm{~m}$ ), which deploy longlines 40 to 55 nautical miles long, of monofilament nylon, with secondary lines of about $15 \mathrm{~m}$ length without wire leaders but with lightsticks connected close to the ' $J$ ' hook (size 9/0) or tuna hook, and which use squid as bait. This fleet is mainly based at northeastern Brazilian ports, targeting swordfish Xiphias gladius, and tunas Thunnus spp. in a wide area of tropical and equatorial Atlantic Ocean, but some vessels could operate in the SW Atlantic Ocean during certain periods of the year. Vessels are able to operate continuously during the day and night due to large operational and storage capacity, staying at sea for several months and deploying more hooks than the national or domestic fleet (see 'Results' for comparison between fleets). The domestic fleet differs from the leased fleet in terms of the small size of its vessels (15 to $28 \mathrm{~m}$ ), and the fact that operational capacity is limited to $1 \mathrm{mo}$ at sea, mainly because the catch is stored in ice rather than frozen. Furthermore, this fleet deploys shorter mainlines, usually using 800 to 1200 hooks per set and a single deployment per day; the bait is usually squid, but also sardines and mackerel are used, and light-sticks are employed when the main target is swordfish. This fleet also targets tunas and swordfish; however, as sharks (Prionace glauca and others) are a significant and sometimes the main component of the catch, a $0.5 \mathrm{~m}$ multifilament steel cable is attached at the terminal section of the secondary line near the hook. This fleet operates mainly at the shelf break of southern Brazil and adjacent international waters (see 'Results' for fishing grounds of both fleets).

Data for this study were collected by seabird observers during 63 pelagic longline fishing cruises made by the Brazilian domestic fleet between January 2001 and November 2007, departing from the main fishing ports of Santos, Itajaí and Rio Grande in southern/southeastern Brazil. Cruises usually lasted 15 to $25 \mathrm{~d}$, and observers collected data on seabird abundance, seabird bycatch and abiotic variables. Overall coverage was 656 sets and 788446 hooks. The number of hooks deployed in each set varied from 230 to 1600 $($ mean $=1110$ hooks $)$.

Seabird abundance around fishing vessels was assessed in 5 counts just before dusk, with 15 min intervals between counts, from 2001 to 2006. This method was adopted because most hooks are deployed at night (thus precluding a census of seabirds), and was considered a suitable proxy of bird numbers attending the vessel before setting, the period of highest probability of bird capture (Brothers et al. 1999). Censuses were carried out before the nautical sunset, i.e. the time when the centre of the sun is $12^{\circ}$ below the horizon, to ensure comparable data collected in different areas and seasons. Seabird abundance in cold months (June to November, 221 censuses) and warm months (December to May, 62 censuses) is presented as frequency of occurrence (absolute and relative), and total and mean number of birds attending the vessel. Censuses were not carried out at all settings either for reasons of safety onboard during bad weather or when the observer was less well trained in seabird identification at sea. The maximum number of birds per species each day (i.e. each 5-count sequence) was used for calculations. The division between cold and warm months is indicated by sea surface temperature off southern Brazil, which is thought to be a major determinant of seabird occurrence in the area (authors' pers. obs.).

Data on the domestic pelagic longline fishing fleet and the leased fleets from 2000 to 2006 were obtained from Brazilian reports of the regional fishery management organization ICCAT (International Commission for the Conservation of Atlantic Tuna), provided by the Standing Committee on Research and Statistics (available at www.iccat.int/). The dynamic of both leased and domestic fleets in terms of variation in number of vessels from 2000 to 2006, and the spatial distribution of fishing effort in terms of numbers of hooks deployed, as exemplified by 2006 data, are presented (Fig. 1; 'Results').

A review of published and unpublished references reporting seabird capture rates in pelagic and demersal (= bottom) longline fisheries was carried out (see Appendix 1, available online as Supplementary Material at: www.int-res.com/articles/suppl/n005p137 _app.pdf). This covers studies in Brazil, Uruguay, the Patagonian shelf and adjacent international waters, but was not exhaustive, particularly where there were several peer reviewed publications on the topic, such as the demersal fisheries on the Patagonian shelf area. Fishing effort was standardized as the number of hooks 
deployed, and capture rates as birds per 1000 hooks. As the capture of seabirds in longline fisheries is a stochastic event we hypothesize that capture rates based on a small number of hooks, and consequently a limited number of trips or during a single season, are not representative of the capture rates. Furthermore, it is reasonable to assume that studies with small or no captures are less likely to be published. Thus, a General Linear Model was carried out using the number of hooks and capture rates reported in a range of studies for both pelagic and bottom longline fisheries to test the hypothesis that estimates of capture rates based on limited sampling are usually overestimated. Capture rates and the number of hooks were transformed $(\ln x+1)$, looking for normality of residuals and homoscedasticity. Because demersal and longline fisheries have different orders of magnitude in reported capture rates and fishing effort, statistical analysis was conducted separately for each of these fisheries. Publications that failed to report overall capture rates by focusing on a single species (e.g. Laich \& Favero 2007) were excluded from statistical analysis. Statistical analysis was performed using Minitab ${ }^{\circledR}$ software, v. 15.

\section{RESULTS}

\section{The Brazilian pelagic longline fishing fleet}

Longline sets and seabird censuses sampled in this study were widespread over a large area throughout the Brazilian EEZ and adjacent international waters (Fig. 1), where most of the domestic Brazilian fleet target swordfish, tunas and sharks (Mayer \& Andrade 2005, our Fig. 2). The overlap between observer coverage in the present study (Fig. 1) and the fishing effort and fishing grounds of the pelagic longline fleets reported to ICCAT is particularly evident for the domestic fleet (Fig. 2). Overall, 2 important fishing
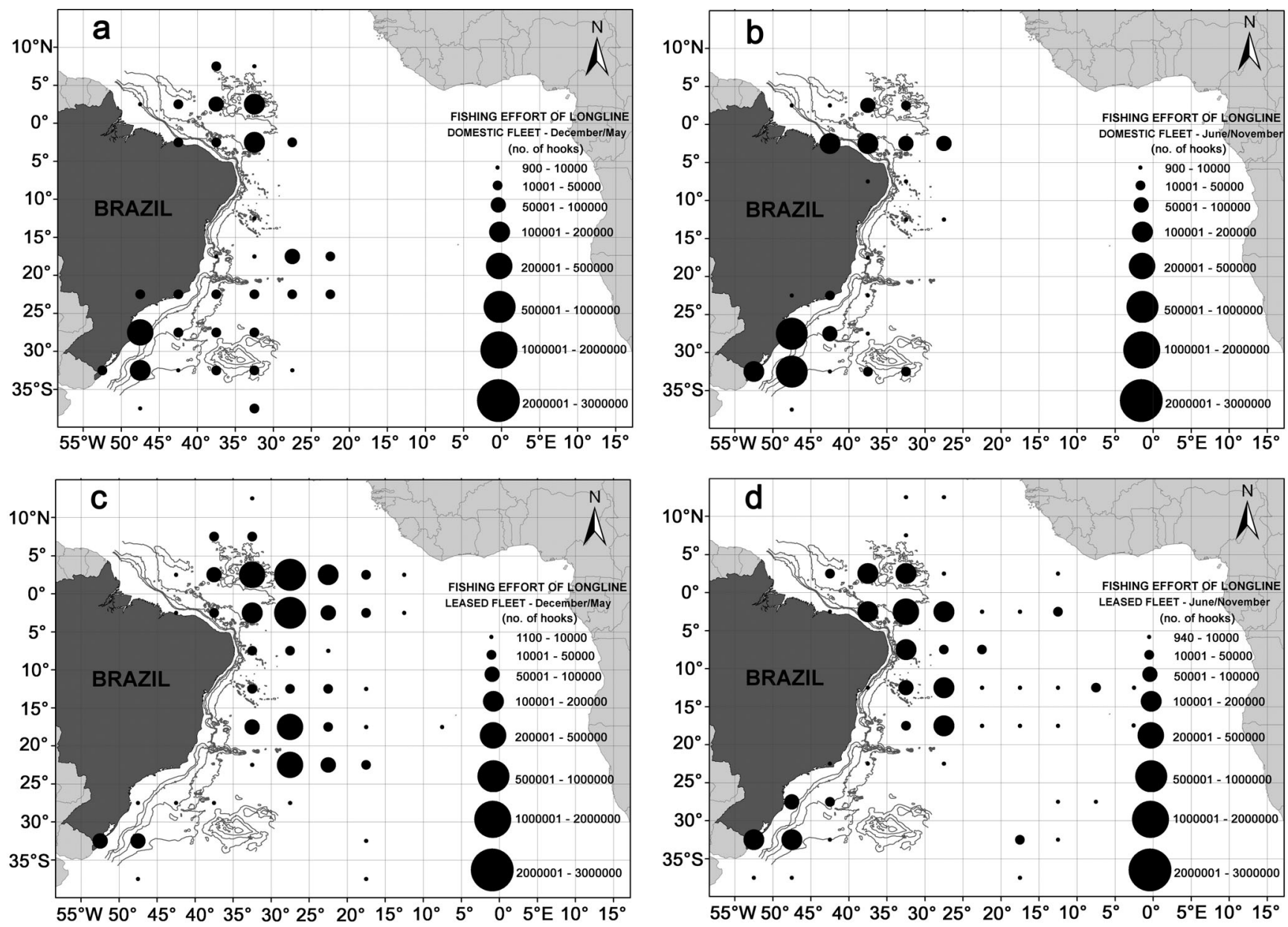

Fig. 2. Spatial distribution of effort of the Brazilian domestic pelagic longline fishing fleet in 2006 (latitude-longitude resolution of $5^{\circ} \times 5^{\circ}$ ) during (a) warm months from December to May, 1.5 million hooks, (b) cold months from June to November, 3.2 million hooks, (c) the leased fleet during warm months from December to May, 3.2 million hooks, and (d) cold months from June to November, 1.9 million hooks 
grounds for the domestic fleet are located in the SW Atlantic, one along the southern Brazilian shelf break, and another in international waters over the Rio Grande Plateau (ca. $33^{\circ} \mathrm{S}, 32^{\circ} \mathrm{W}$, Figs. 1 \& 2). Domestic and leased fleets also operate in northeastern areas, departing mainly from the port of Cabedelo, where overlap with the distribution of most seabird species is expected to be low. However, some of those vessels operate in southern fishing grounds during winter, a characteristic of this dynamic fleet that requires further investigation.

Comparing domestic and leased fleets, it is noticeable that the main effort of the leased fleet is in northeastern fishing grounds, and that of the domestic fleet in southern grounds (Fig. 2). Thus, the main overlap between seabird distribution and the pelagic longline occurs during winter from $20^{\circ} \mathrm{S}$ southward, mainly, but not exclusively, with the national fleet, and is variable between years.

The variation in number of vessels of the pelagic longline fleet based in Brazil (leased and domestic) is presented in Fig. 3. From 2000 to 2006, the number of vessels varied from 89 to 129 , with a consistent decrease for the leased fleet and a slight increase for the domestic fleet (Fig. 3). However, the fishing effort in terms of number of hooks deployed by both the domestic and leased fishing fleets during this period ranged from 4.6 million hooks in 2003 to 15.4 million in 2000. After 2003, there was an increase in fishing effort, and in 2006, the most recent year with information currently available, 9 million hooks were deployed, despite a decrease in number of vessels. The effort of the leased fleet was higher than that of the domestic fleet during all years, particularly in 2000 (92\% of total), but also in 2006 when it represented $52 \%$, despite accounting for only $1 / 3$ of the vessels. This occurs because leased vessels are larger, deploy more hooks per set, operate



Fig. 3. Annual variations in the number of pelagic longline vessels based in Brazilian ports from 2000 to 2006 for the domestic and leased fleets. Total number of vessels is shown above the bars continuously throughout the day, and have higher operational capacity, staying at sea for several months.

\section{Seabird abundance}

At least 21 seabird species were recorded attending Brazilian pelagic longline vessels (Table 1). Apart from occasional skuas and jaegers (genus Stercorarius) and frigatebirds, all other species were albatrosses and petrels, truly pelagic seabirds, as expected since sets occurred in offshore waters. The spectacled petrel Procellaria conspicillata was the most abundant species attending longline fishing vessels off Brazil around the year, both in terms of frequency of occurrence and number (Table 1). Atlantic yellow-nosed albatrosses Thalassarche chlororhynchos, spectacled petrels and great shearwaters Puffinus gravis showed similar abundance throughout the year, whereas seasonally abundant species during cold months were whitechinned petrels Procellaria aequinoctialis, Cape petrels Daption capense, black-browed albatrosses Thalassarche melanophris (mostly first-year juveniles), southern fulmars Fulmarus glacialoides, and Wilson's storm petrels Oceanites oceanicus.

\section{Seabird capture in the Brazilian pelagic longline fishery}

At least 5 seabird species were caught on fishing hooks during this study: black-browed, Atlantic yellow-nosed and wandering Diomedea exulans albatrosses, white-chinned and spectacled petrels (Table 2). A total of 178 birds were captured, with a maximum of 40 birds in a single trip and 29 in a single set when 1225 hooks were deployed. Capture rates calculated by season and year varied from 0 to 0.542 birds per 1000 hooks with higher rates during the cold season (Table 3). The capture rates were variable between trips, with half of the trips resulting in no captures (31 out of 63 trips), and only 61 out of 656 sets $(11 \%)$ capturing birds. Overall, a capture rate of 0.229 birds per 1000 hooks was recorded. The black-browed albatross was the most common species caught $(55 \%$ of captured birds), followed by the white-chinned petrel (26\%) (Table 2). Capture rate of the spectacled petrel was ranked only fourth although it was the most frequent and abundant species attending vessels. Birds are captured predominantly during cold months, when there is greater overlap in southern Brazil between large numbers of species more prone to capture, such as the black-browed albatross and the white-chinned petrel, and higher fishing effort of the pelagic longline fleet. 
Table 1. Abundance of seabirds attending longline fishing vessels off Brazil measured by frequency of occurrence (FO) and relative frequency (FO\%), mean and total number of birds between 2001 and 2006. Values were obtained from the maximum number counted on each census day just before dusk. Cold months are from June to November (221 censuses) and warm months from December to May (62 censuses). $\mathrm{n}=$ no. of birds observed

\begin{tabular}{|c|c|c|c|c|c|c|c|c|}
\hline \multirow[t]{2}{*}{ Species } & \multicolumn{4}{|c|}{ _ June-November __ } & \multicolumn{4}{|c|}{ — December-May _ } \\
\hline & $\mathrm{FO}$ & $\mathrm{FO} \%$ & $\mathrm{n}$ & Mean & $\mathrm{FO}$ & $\mathrm{FO} \%$ & $\mathrm{n}$ & Mean \\
\hline Spectacled petrel Procellaria conspicillata & 191 & 86.4 & 1929 & 8.7 & 41 & 66.1 & 277 & 4.5 \\
\hline White-chinned petrel Procellaria aequinoctialis & 103 & 46.6 & 638 & 2.9 & 15 & 24.2 & 31 & 0.5 \\
\hline Atlantic yellow-nosed albatross Thalassarche chlororhynchos & 139 & 62.9 & 456 & 2.1 & 21 & 33.9 & 41 & 0.7 \\
\hline Great shearwater Puffinus gravis & 101 & 45.7 & 432 & 2.0 & 35 & 56.5 & 163 & 2.6 \\
\hline Cape petrel Daption capense & 88 & 39.8 & 427 & 1.9 & 3 & 4.8 & 4 & $<0.1$ \\
\hline Black-browed albatross Thalassarche melanophris & 97 & 43.9 & 372 & 1.7 & 19 & 30.6 & 38 & 0.6 \\
\hline Southern fulmar Fulmarus glacialoides & 14 & 6.3 & 86 & 0.4 & 0 & 0 & 0 & 0 \\
\hline Manx shearwater Puffinus puffinus & 5 & 2.3 & 99 & 0.4 & 2 & 3.2 & 3 & $<0.1$ \\
\hline Wilson's storm petrel Oceanites oceanicus & 38 & 17.2 & 72 & 0.3 & 1 & 1.6 & 1 & $<0.1$ \\
\hline Large albatross Diomedea spp. (including dabbenena/exulans) & 24 & 10.9 & 49 & 0.2 & 0 & 0 & 0 & 0 \\
\hline Atlantic petrel Pterodroma incerta & 14 & 6.3 & 28 & 0.1 & 4 & 6.5 & 5 & $<0.1$ \\
\hline Southern royal albatross Diomedea epomophora & 2 & 0.9 & 2 & $<0.1$ & 0 & 0 & 0 & 0 \\
\hline Northern royal albatross Diomedea sanfordi & 2 & 0.9 & 2 & $<0.1$ & 0 & 0 & 0 & 0 \\
\hline Soft-plumaged petrel Pterodroma mollis & 1 & 0.5 & 1 & $<0.1$ & 0 & 0 & 0 & 0 \\
\hline Unidentified Pterodroma sp. & 1 & 0.5 & 3 & $<0.1$ & 0 & 0 & 0 & 0 \\
\hline Sooty shearwater Puffinus griseus & 1 & 0.5 & 1 & $<0.1$ & 0 & 0 & 0 & 0 \\
\hline Cory's shearwater Calonectris diomedea & 5 & 2.3 & 14 & $<0.1$ & 0 & 0 & 0 & 0 \\
\hline Southern giant petrel Macronectes giganteus & 6 & 2.7 & 11 & $<0.1$ & 0 & 0 & 0 & 0 \\
\hline Northern giant petrel Macronectes halli & 1 & 0.5 & 1 & $<0.1$ & 0 & 0 & 0 & 0 \\
\hline Giant petrels Macronectes sp. & 4 & 1.8 & 5 & $<0.1$ & 0 & 0 & 0 & 0 \\
\hline White-bellied storm petrel Fregetta grallaria & 1 & 0.5 & 1 & $<0.1$ & 0 & 0 & 0 & 0 \\
\hline Skuas and jaegers Stercorarius spp. & 2 & 0.9 & 3 & $<0.1$ & 0 & 0 & 0 & 0 \\
\hline Frigatebirds Fregata sp. & 2 & 0.9 & 2 & $<0.1$ & 0 & 0 & 0 & 0 \\
\hline
\end{tabular}

Table 2. Capture rate of seabird species in the domestic pelagic longline fishery in Brazil from 2001 to 2007 ( $\mathrm{n}=$ 788446 hooks)

\begin{tabular}{|lc|}
\hline Species & $\begin{array}{c}\text { Capture rate } \\
\text { (birds/1000 hooks) }\end{array}$ \\
\hline $\begin{array}{l}\text { Black-browed albatross } \\
\text { Thalassarche melanophris }\end{array}$ & 0.126 \\
$\begin{array}{l}\text { Atlantic yellow-nosed albatross } \\
\text { Thalassarche chlororhynchos }\end{array}$ & 0.011 \\
Unidentified albatrosses Thalassarche sp. & 0.018 \\
Wandering albatross Diomedea exulans & 0.001 \\
Unidentified albatrosses Diomedea sp. & 0.005 \\
$\begin{array}{l}\text { White-chinned petrel } \\
\text { Procellaria aequinoctialis }\end{array}$ & 0.059 \\
Spectacled petrel Procellaria conspicillata & 0.008 \\
Overall capture rate & 0.229 \\
\hline
\end{tabular}

\section{Seabird capture rates reported for the SW Atlantic}

Seabird capture rates in the SW Atlantic have been reported in the literature from 1991 to 2007. At least 28 studies focused on incidental capture of albatrosses and petrels in demersal (17 studies) and pelagic (16 studies) longlines (Appendix 1). Sampling methods included analysis of logbooks, interviews with fishing skippers or other fishermen, observers primarily dedi- cated to collecting fishery rather than seabird data making occasional observations of seabird bycatch, and seabird-dedicated onboard observers. The reliability of data obtained by each method is obviously variable, but biases associated with methods are difficult to evaluate, due to the difficulty of disentangling different factors and because some studies failed to provided sufficiently accurate details. For the Brazilian pelagic longline fishery there is a trend towards lower capture rates in the dataset provided by fishermen through logbooks or interviews. Data obtained by logbooks or interviews tended to have higher coverage (i.e. more hooks sampled), but their reliability is difficult to assess. Fishing effort reported was also very variable, from a few thousands up to 150 million hooks. Demersal longline studies in general reported lower mean capture rates ( 0.005 to 0.41 birds per 1000 hooks) and were more consistent in having less variation in capture rates and by relying on samples with higher fishing effort. On the other hand, in the pelagic longline fishery the capture rates varied among studies from zero to 5.03 birds per 1000 hooks, with variability within some studies, including some highly skewed values (Fig. 4).

Negative correlations between fishing effort (measured as number of hooks set) and capture rates were found for the demersal $(F=10.08, \mathrm{df}=11, \mathrm{p}=0.01)$ and 
pelagic $(F=14.56, \mathrm{df}=12, \mathrm{p}=0.003)$ fisheries in the SW Atlantic Ocean (Fig. 4). Variation in number of hooks explained $45.2 \%$ of the variation in capture rates in the demersal fishery and $53.0 \%$ in the pelagic fishery. This result suggests that studies based on low numbers of hooks often greatly overestimate seabird capture rates.
Table 3. Seasonal and inter-annual variation in capture rates of seabirds (birds per 1000 hooks) in the domestic pelagic longline fishery of Brazil, from 2001 to 2007. Standard deviation (SD) of capture rates was calculated from a binomial probability distribution, taking into account the number of hooks deployed and the number of birds captured. Overall capture rate $=0.229$ birds per 1000 hooks and number of hooks deployed $=788446$ hooks. - : not sampled

\begin{tabular}{|ccccr|}
\hline \multirow{2}{*}{ Year } & \multicolumn{2}{c}{$\begin{array}{c}\text { Warm months (December-May) } \\
\text { Capture rate } \pm \text { 1 SD }\end{array}$} & No. hooks & \multicolumn{2}{c|}{$\begin{array}{c}\text { Cold months (June-November) } \\
\text { Capture rate } \pm \text { 1 SD }\end{array}$} & No. hooks \\
\hline 2001 & 0.000 & 23893 & 0.000 & 36900 \\
2002 & $0.217 \pm 0.063$ & 55400 & $0.177 \pm 0.059$ & 50900 \\
2003 & - & - & $0.124 \pm 0.051$ & 48400 \\
2004 & 0.000 & 5400 & $0.036 \pm 0.021$ & 82958 \\
2005 & 0.000 & 39190 & $0.129 \pm 0.032$ & 123940 \\
2006 & $0.073 \pm 0.051$ & 27390 & $0.415 \pm 0.088$ & 53045 \\
2007 & $0.142 \pm 0.050$ & 56460 & $0.542 \pm 0.054$ & 184570 \\
\hline
\end{tabular}
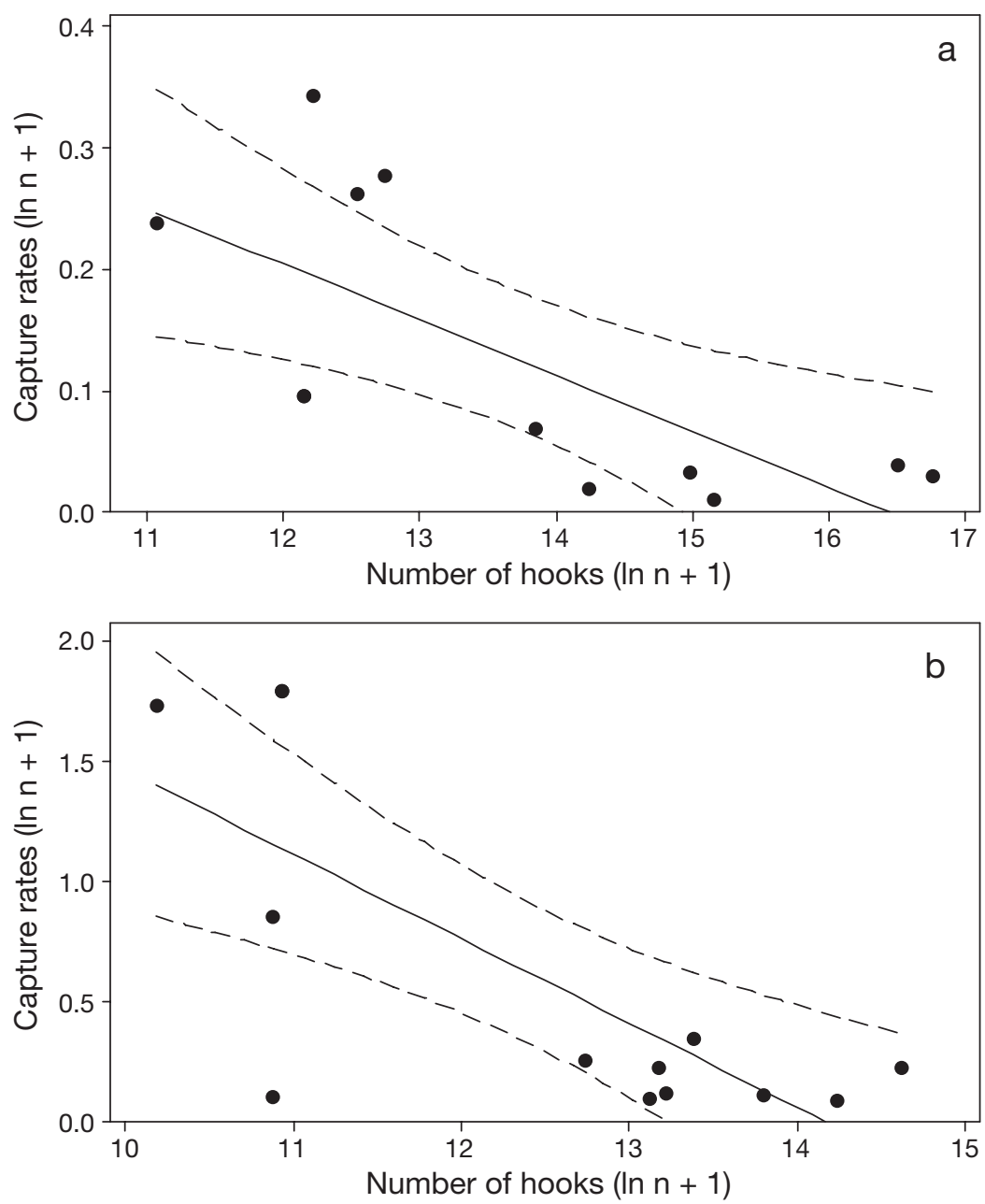

Fig. 4. Correlation between number of hooks and capture rates measured by birds per 1000 hooks for (a) demersal and (b) pelagic longline fisheries. Values are transformed $(\ln n+1)$, trend line and $95 \%$ confidence intervals are shown

\section{DISCUSSION}

\section{Seabird capture in the Brazilian pelagic longline fishery}

Several species of albatross and petrel are captured by the Brazilian pelagic longline fishery and, apart from those reported here (Table 1), Tristan Diomedea dabbenena, southern royal $D$. epomophora, and northern royal $D$. sanfordi albatrosses, great shearwaters and southern fulmars are known to be affected (Neves \& Olmos 1997, Olmos et al. 2001, Vaske Jr. 1991). In the present study, black-browed albatrosses and white-chinned petrels showed the highest capture rates, in agreement with previous studies across the entire SW Atlantic, in both pelagic and demersal longline fisheries. In contrast, the Atlantic yellow-nosed albatross and spectacled petrel are captured particularly off the coasts of Uruguay and Brazil (Jiménez \& Domingo 2007, present study), coinciding with a more northern distribution of these species in the SW Atlantic. On the other hand, the high abundance of spectacled petrels attending fishing vessels contrast with the limited capture rate, as it was ranked 4 th in number of fatalities.

Capture rates reported here varied greatly according to season, trip, and set, an inherent characteristic of seabird bycatch in longline fisheries, where only a few sets capture birds and most have no capture $(91 \%$ in the present study, and $85 \%$ in Brothers et al. 1999, Reid \& Sullivan 2004).

\section{Seabird bycatch in the SW Atlantic Ocean}

An early report of incidental mortality of seabirds in SW Atlantic waters was provided by Croxall \& Prince (1990) who used band recoveries of wandering albatrosses breeding in 
South Georgia Islands and killed by the tuna longline fishery off South America. However, capture rates were first calculated in 1987 to 1990 (Vaske Jr. 1991). This and other early studies of capture rates reported high values, such as 1.35 birds per 1000 hooks (Vaske Jr. 1991 and Appendix 1) in the tuna longline fishery in southern Brazil during winter and spring (= 'cold months' in the present study) or 4.7 birds per 1000 hooks for the Uruguayan fleet operating in the same area and with no weighted swivels (Stagi et al. 1997). However, high capture rates are probably due to the lower number of hooks analysed, and to particular features of the fishing gear and cruises taking place in winter, when large numbers of species vulnerable to capture are present in the area. During the last 2 decades, at least 28 studies have focused on the incidental capture of seabirds in demersal and pelagic longline fisheries in Brazil, Uruguay, Patagonian shelf and Malvinas/Falkland Islands (Appendix 1). These studies encompass an area from southeastern Brazil (ca. $20^{\circ} \mathrm{S}$ ) to sub-Antarctic waters (ca. 58 ${ }^{\circ} \mathrm{S}$ ) and include a wide range of fishing methods, targeted species, sampling methods, sampling effort and accuracy of data. Most studies with large numbers of hooks sampled were obtained from logbooks, interviews with fishers or non-dedicated seabird observers. For both demersal and pelagic fisheries, captures based on limited sampling (i.e. small number of hooks) tend to report higher capture rates (Fig. 4). Early studies were fundamental in identifying the problem, species, area and fisheries where captures occurred and also illustrate the range of situations that determine high captures. Currently, estimations of numbers of birds killed will greatly benefit from robust data obtained by dedicated seabird observers, larger and representative datasets, and analysed using more robust statistics, such as multi-stage analysis with stratified data (e.g. in Reid et al. 2004, Laich \& Favero 2007 for the demersal longline fishery), rather than simplistic extrapolations of capture rates and total fishing effort for a given fleet or area. It is in the general interest of all, and the responsibility of regulatory organizations and governments, to provide adequate conditions for obtaining more rigorous data. The importance of large data sets and reliable data collected by onboard observers is evident in the work by Jiménez (2005) and Jiménez \& Domingo (2007) where circumstances of incidental captures were identified: the shelf break off Uruguay as an area of high incidental mortality, as well as hook setting during daylight hours or bright moon phases, and cold waters, were identified as important factors accounting for seabird mortality. It is surprising that even basic data such as numbers of hooks, season, or type of longline are frequently not reported in capture rate estimates (Appendix 1). However, there has been a general improvement in recent datasets and the use of analytical tools since the pioneering study of Vaske Jr. (1991). Thus, considering the various capture rates for the pelagic longline fisheries (Appendix 1), those based on large datasets, several cruises, vessels, fishing gear, areas, and collected by seabird-dedicated onboard observers appear to place representative annual estimates of captures in the range of 0.2 to 0.4 birds per 1000 hooks.

Estimates of population-level impacts are expected to be greatly influenced by the values used in the model (Inchausti \& Weimerskirch 2001, Hyrenbach \& Dotson 2003, Lewison et al. 2005). Lewison et al. (2005) and Lewison \& Crowder (2007) discuss the problems associated with incidental capture rates and their limited reliability for estimation of number of individuals captured for a fleet or an ocean basin. Additionally, this sort of exercise suffers from the high dynamics of longline fleets, which vary spatially, temporally and in size (Hyrenbach \& Dotson 2003, Tuck et al. 2003, Mayer \& Andrade 2005, present study). For instance, the number of vessels in the Brazil-based pelagic longline fleets (leased and domestic) is also variable between years (Fig. 3) and highly dynamic, which has important implications for the capture of albatrosses and petrels and the mitigation of this problem.

\section{Overlap between fishery and seabirds and implications for conservation}

Black-browed and Atlantic yellow-nosed albatrosses, spectacled and white-chinned petrels, and great shearwaters were the most numerous seabirds attending pelagic longliners in Brazil. This pattern was expected and corroborates previous information on seabirds attending longline vessels in Brazil (Olmos 1997, Olmos \& Bugoni 2006, Neves et al. 2006b). The spectacled petrel is endemic to Inaccessible Island, Tristan da Cunha Archipelago, and has a small breeding population estimated at 20000 adult birds (Ryan et al. 2006). The bulk of the spectacled petrel population appears to be concentrated off Brazil and Uruguay, as it is rare off South African wintering grounds (Camphuysen \& van der Meer 2000, Camphuysen 2001). Spectacled petrels in the SW Atlantic are probably immature birds as well as breeding birds performing long foraging trips, as recorded for the foraging trips of white-chinned petrels (Weimerskirch et al. 1999). The Atlantic yellow-nosed albatross had a high frequency of occurrence in cold months $(63 \%)$, but with small numbers attending vessels. This species also has a small breeding population endemic to the Tristan da Cunha Archipelago (Cuthbert \& Sommer 2004), and immature as well as mature birds, differentiated by bill 
colours and plumage moult, are found in the SW Atlantic throughout the year and are captured in a range of fisheries (Bugoni et al. 2008, present study). The only other species abundant throughout the year is the great shearwater, the largest flocks of which are during autumn, during their journey to the North Atlantic Ocean where they winter, and again in spring, during their southward migration to the Tristan da Cunha breeding grounds (Metcalf 1966, Neves et al. 2006b), or birds using the area for moult (L. Bugoni \& R. W. Furness unpubl. data). During cold months, southern migrants reach southern Brazilian waters, particularly the black-browed albatross and the whitechinned petrel (Phillips et al. 2006), which are the most abundant species in the area as well as the most frequently captured within this period. In other areas, the capture in summer (i.e. the breeding period) is higher than in cold months (Brothers et al. 1999), confirming that most albatrosses and petrels have neither a safe area nor season, being killed by pelagic and bottom longline throughout the year and in many different areas. The SW Atlantic Ocean is an important area for juvenile black-browed albatrosses from the Malvinas/ Falkland Islands, but also for adults of this and other populations (BirdLife International 2004, Phillips et al. 2005). Severe decline of the black-browed albatross global population is attributed to pelagic longline fisheries in the SW Atlantic, as well as to a range of other fisheries (Neves et al. 2006a, 2007, Sullivan et al. 2006, Bugoni et al. 2008).

The displacement of the leased fleet to northeast Brazil during the summer months (Fig. 2) shows minor overlap with albatross and petrel distribution during this period, which could suggest negligible capture rates. However, the operation of some leased vessels in southern waters is of concern. Furthermore, preliminary data collected by onboard observers (non-seabird dedicated) in 2005 shows high numbers of great shearwaters, as well as lower numbers of threatened species, being captured; this raises concern both because of the high fishing effort in this area and because of the reports of a range of species being captured (Neves et al. 2007). There is no study on capture rates of the fleet based in northeastern Brazilian ports, and this requires urgent study. The dynamic nature of pelagic longline fleets in Brazil and elsewhere (Hyrenbach \& Dotson 2003) suggests that continuous monitoring of the fleets is necessary. Non-negligible capture rates of spectacled petrels, Atlantic yellow-nosed, Tristan and wandering albatrosses in southern Brazil and Uruguay (Jiménez \& Domingo 2007, present study) are a major concern because their global populations are small. Also abundant in summer, these species are affected by the longline fishing during this time of the year, when the Brazilian fishing fleet is active over a large area in southeastern Brazilian waters, but also across the Rio Grande Plateau.

Improving data on capture rates in general and in poorly studied fisheries in particular is recommended, especially for those fisheries using hook-and-line methods in Brazil (Bugoni et al. 2008) and the northeastern leased fleet. For better studied fleets, such as the national pelagic fleet based in southern Brazilian ports, detailed analysis of environmental factors and fishing conditions affecting the incidental capture of seabirds is necessary in order to delineate effective conservation strategies. In addition, the implementation of actions suggested in national plans of action (NPOA-Seabirds) available for all coastal countries with jurisdiction on the adjacent oceanic waters of the SW Atlantic is urgently required, given the well established nature of the problem and their significance in the decline of several species. Despite recent studies based on large datasets reporting lower capture rates for the pelagic longline in comparison with early reports, this is probably due to better sampling coverage and not to improvement in mitigation of captures and conservation actions (but see e.g. Otley et al. 2007 for data on the bottom longline fishery). The known capture rates for a range of fisheries and throughout the SW Atlantic are well above sustainable or acceptable levels.

Acknowledgements. Special thanks are due to the captains of the fishing vessels and the fishing companies Imaipesca, Itafish and Kowalsky for cooperation with Projeto Albatroz and also to our dedicated seabird observers. Thanks are also due to the Projeto Albatroz official sponsor Petrobras through Programa Petrobras Ambiental, other sponsors such as the Special Secretariat of Aquaculture and Fisheries (SEAP/PR), Fundação O Boticário de Proteção à Natureza, Royal Society for the Protection of Birds (RSPB), PROBIO-MMA-GEF and its partners IBAMA and Projeto Tamar. L.B. and D.S.M. received scholarships from the CAPES Foundation. The authors are grateful to R. W. Furness, J. P. Croxall and R. A. Phillips for comments on an earlier version, which greatly improved the manuscript and to 2 anonymous reviewers.

\section{LITERATURE CITED}

BirdLife International (2004) Tracking ocean wanderers: the global distribution of albatrosses and petrels. Results from the Global Procellariiform Tracking Workshop, 1-5 September, 2003, Gordon's Bay, South Africa. BirdLife International, Cambridge

Brothers NP, Cooper J, Løkkeborg S (1999) The incidental catch of seabirds by long-line fisheries: worldwide review and technical guidelines for mitigation. FAO Fisheries Circular No. 937, FAO, Rome

Bugoni L, Neves TS, Leite NO Jr, Carvalho D and others (2008) Potential bycatch of seabirds and turtles in hookand-line fisheries of the Itaipava Fleet, Brazil. Fish Res 90:217-224

Camphuysen CJ (2001) The distribution of spectacled petrels Procellaria conspicillata in the south-eastern Atlantic. Atl Seabirds 3:113-124 
Camphuysen KCJ, van der Meer J (2000) Notes on the distribution of the spectacled petrel Procellaria conspicillata in the Southern Ocean. Atl Seabirds 2:13-18

Castello JP (1998) Teleósteos pelágicos. In: Seelinger U, Odebrecht C, Castello JP (eds) Os ecossistemas costeiro e marinho do extremo sul do Brasil. Ed. Ecoscientia, Rio Grande, p 137-143

CBRO (2007). Lista das aves do Brasil, 6th edn (16 de agosto de 2007). Comitê Brasileiro de Registros Ornitológicos, Sociedade Brasileira de Ornitologia. Available at: www. cbro.org.br (02/12/07)

Croxall JP, Prince PA (1990) Recoveries of wandering albatrosses Diomedea exulans ringed at South Georgia. Ringing Migr 11:43-51

Cuthbert R, Sommer E (2004) Population size and trends of four globally threatened seabirds at Gough Island, South Atlantic Ocean. Mar Ornithol 32:97-103

Cuthbert R, Sommer E, Ryan P, Cooper J, Hilton G (2004) Demography and conservation of the Tristan albatross Diomedea [exulans] dabbenena. Biol Conserv 117: 471-481

Efe MA, Musso CM (2001) Primeiro registro de Puffinus lherminieri Lesson, 1839 no Brasil. Nattereria 2:21-23

Favero M, Khatchikian CE, Arias A, Rodriguez MPS, Cañete G, Mariano-Jelicich R (2003) Estimates of seabird by-catch along the Patagonian shelf by Argentine longline fishing vessels, 1999-2001. Bird Conserv Int 13:273-281

Furness RW (2003) Impacts of fisheries on seabird communities. Sci Mar 67:33-45

Gales R (1997) Albatross populations: status and threats. In: Robertson G, Gales R (eds) Albatross biology and conservation.Surrey Beatty \& Sons, Chipping Norton, p 20-45

Garcia CAE (1998) Oceanografia física. In: Seelinger U, Odebrecht C, Castello JP (eds) Os ecossistemas costeiro e marinho do extremo sul do Brasil. Ed. Ecoscientia, Rio Grande, p 104-106

Grémillet D, Pichegru L, Kuntz G, Woakes AG, Wilkinson S, Crawford RJM, Ryan PG (2008) A junk-food hypothesis for gannets feeding on fishery waste. Proc R Soc Lond B Biol Sci 275:1149-1156

Hyrenbach KD, Dotson RC (2003) Assessing the susceptibility of female black-footed albatross (Phoebastria nigripes) to longline fisheries during their post-breeding dispersal: an integrated approach. Biol Conserv 112:391-404

Inchausti P, Weimerskirch H (2001) Risks of decline and extinction of the endangered Amsterdam albatross and the projected impact of long-line fisheries. Biol Conserv 100:377-386

Jiménez S (2005) Captura incidental de aves marinas en el Océano Atlántico Sudoccidental: interacción con la flota uruguaya de palangre pelágico. Bachelor's thesis, Universidad de la Republica, Montevideo

Jiménez S, Domingo A (2007) Albatros y petreles: su interacción con la flota de palangre pelágico uruguaya en el Atlántico Sudoccidental. Col Vol Sci Pap ICCAT 60:2110-2117

Laich AG, Favero M (2007) Spatio-temporal variation in mortality rates of white-chinned petrels Procellaria aequinoctialis interacting with longliners in the south-west Atlantic. Bird Conserv Int 17:359-366

Lewison RL, Crowder LB (2007) Putting longline bycatch of sea turtles into perspective. Conserv Biol 21:79-86

Lewison RL, Nel DC, Taylor F, Croxall JP, Rivera KS (2005) Thinking big - taking a large-scale approach to seabird bycatch. Mar Ornithol 33:1-5

Luigi G, Bugoni L, Fonseca-Neto FP, Teixeira DM (2008) Biologia e conservação do petrel-de-trindade, Pterodroma arminjoniana, na ilha da Trindade, Atlântico sul. In: Mohr
LV, Castro JWA, Costa PMS, Alves RJV (eds) Ilhas oceânicas brasileiras: da pesquisa ao manejo. Vol 2. Ministério do Meio Ambiente, Brasília (in press)

Mayer FP, Andrade HA (2005) Swordfish (Xiphias gladius) and blue shark (Prionace glauca) fishery and the dynamics of the fleet off the southeastern Brazilian coast. Col Vol Sci Pap, ICCAT 58:1204-1214

Metcalf WG (1966) Observations of migrating great shearwaters Puffinus gravis off the Brazilian coast. Ibis 108: $138-140$

Montevecchi WA (2002) Interactions between fisheries and seabirds. In: Schreiber EA, Burger J (eds) Biology of marine birds. CRC Press, Boca Raton, FL, p 527-557

Nel DC, Ryan PG, Crawford RJM, Cooper J, Huyser OAW (2002) Population trends of albatrosses and petrels at subAntarctic Marion Island. Polar Biol 25:81-89

Neves T, Olmos F (1997) Albatross mortality in fisheries off the coast of Brazil. In: Robertson G, Gales R (eds) Albatross biology and conservation. Surrey Beatty \& Sons, Chipping Norton, p 214-219

Neves TS, Olmos F, Peppes FV, Mohr LV (2006a) National Plan of Action for the Conservation of Albatrosses and Petrels - NPOA-Brazil. Ibama, Brasília

Neves T, Vooren CM, Bugoni L, Olmos F, Nascimento L (2006b) Distribuição e abundância de aves marinhas no sudeste-sul do Brasil. In: Neves T, Bugoni L, RossiWongtschowski CLB (eds). Aves oceânicas e suas interações com a pesca na região Sudeste-Sul do Brasil. USP, REVIZEE: Score Sul, São Paulo, p 11-35

Neves T, Mancini PL, Nascimento L, Miguéis AMB, Bugoni L (2007) Overview of seabird bycatch by Brazilian fisheries in the South Atlantic Ocean. Col Vol Sci Pap ICCAT 60: 2085-2093

Olmos F (1997) Seabirds attending bottom long-line fishing off southeastern Brazil. Ibis 139:685-691

Olmos F, Bugoni L (2006) Agregações de aves marinhas associadas à pesca de espinhel-de-fundo na região SudesteSul do Brasil. In: Neves T, Bugoni L, Rossi-Wongtschowski CLB (eds) Aves oceânicas e suas interações com a pesca na região Sudeste-Sul do Brasil. USP, REVIZEE: Score Sul, São Paulo, p 69-81

Olmos F, Neves TS, Bastos GC (2001) A pesca com espinhéis e a mortalidade de aves marinhas no Brasil. In: Albuquerque JLB, Cândido JF Jr, Straube FC, Roos AL (eds) Ornitologia e conservação, da ciência às estratégias. Editora Unisul, Tubarão, p 327-337

> Olson DB, Podestá GP, Evans RH, Brown OB (1988) Temporal variations in the separation of Brazil and Malvinas Currents. Deep-Sea Res 35:1971-1990

Otley HM, Reid TA, Pompert J (2007) Trends in seabird and Patagonian toothfish Dissostichus eleginoides longliner interactions in Falkland Island waters, 2002/03 and 2003/2004. Mar Ornithol 35:47-55

Perez JAA, Wahrlich R (2005) A bycatch assessment of the gillnet monkfish Lophius gastrophysus fishery off southern Brazil. Fish Res 72:81-95

> Phillips RA, Silk JRD, Croxall JP, Afanasyev V, Bennett VJ (2005) Summer distribution and migration of nonbreeding albatrosses: individual consistencies and implications for conservation. Ecology 86:2386-2396

> Phillips RA, Silk JRD, Croxall JP, Afanasyev V (2006) Yearround distribution of white-chinned petrels from South Georgia: relationships with oceanography and fisheries. Biol Conserv 129:336-347

Reid TA, Sullivan BJ (2004) Longliners, black-browed albatross mortality and bait scavenging in Falkland Island waters: what is the relationship? Polar Biol 27:131-139 
Reid TA, Sullivan BJ, Pompert J, Enticott JW, Black AD (2004) Seabird mortality associated with Patagonian toothfish (Dissostichus eleginoides) longliners in Falkland Islands waters. Emu 104:317-325

Ryan PG, Dorse C, Hilton GM (2006) The conservation status of the spectacled petrel Procellaria conspicillata. Biol Conserv 131:575-583

Stagi A, Vaz-Ferreira R, Marín Y, Joseph L (1997) The conservation of albatrosses in Uruguayan waters. In: Robertson G, Gales R (eds) Albatross, biology and conservation. Surrey Beatty \& Sons, Chipping Norton, p 220-224

Sullivan BJ, Reid TA, Bugoni L (2006) Seabird mortality on factory trawlers in the Falkland Islands and beyond. Biol Conserv 131:495-504

Thompson KR, Riddy MD (1995) Utilization of offal and discards from 'finfish' trawlers around the Falkland Islands by the black-browed albatross Diomedea melanophris.

Editorial responsibility: Daniel Oro,

Esporles, Spain
Ibis 137:198-206

Tuck GN, Polacheck T, Croxall JP, Weimerskirch W (2001) Modelling the impact of fishery by-catches on albatross populations. J Appl Ecol 38:1182-1196

Tuck GN, Polacheck T, Bulman CM (2003) Spatio-temporal trends of longline fishing effort in the Southern Ocean and implications for seabird bycatch. Biol Conserv 114:1-27

Vaske T Jr (1991) Seabirds mortality on longline fishing for tuna in Southern Brazil. Cienc Cult 43:388-390

- Votier SC, Furness RW, Bearhop S, Crane JE and others (2004) Changes in fisheries discard rates and seabird communities. Nature 427:727-730

Weimerskirch H, Catard A, Prince PA, Cherel Y, Croxall JP (1999) Foraging white-chinned petrels Procellaria aequinoctialis at risk: from the tropics to Antarctica. Biol Conserv 87:273-275

Submitted: March 5, 2008; Accepted: June 11, 2008

Proofs received from author(s): September 11, 2008 